\title{
Impact of Unemployment on Engineering Graduates in Recession
}

\author{
Chandra Sekhar Patro ${ }^{1}$, B.Lohit ${ }^{2}$ \\ ${ }^{1}$ Assistant Professor, Department of Management Studies, VITS College of Engineering, Visakhapatnam, \\ Andhra Pradesh, India. \\ ${ }^{2}$ B.Tech. Student, Department of Electronics and Communication Engineering, VITS College of Engineering, \\ Visakhapatnam, Andhra Pradesh, India.
}

\begin{abstract}
Today, unemployment is up, jobs are scarce, and layoffs have become common across the organizations. Engineering education is a process of developing techno human resources, which are to be used later as input to industry which in turn produces goods and services for the societal use. Having considered the current situation of the engineering educational system and the quality of all its individual components it can be noticed that the awareness of the importance of education as a foundation for the growth and development of the country, such as India, is not strong enough. Engineering graduates passing out from educational institutions have to fulfil modern and high standard requirements that are needed by industry. In today's arena the most common word we come across is recession. Recession leads to a decreased demand for goods and services, which in turn leads to a decrease in production, lay-offs and rise in unemployment.

The present paper projects the impact of unemployment on engineering graduates at the time of recession. It also presents a case study based on the survey statistics conducted by the Department of Labour, New Zealand to develop the SoWL.

Keywords: Education, Engineering, Graduates, Recession, Unemployment.
\end{abstract}

\section{Introduction}

A recession is a decline in a country's gross domestic product (GDP) growth for two or more consecutive quarters of a year. A recession is also preceded by several quarters of slowing down. A recession normally takes place when consumers lose confidence in the growth of the economy and spend less. An economy, which grows over a period of time, tends to slow down the growth as a part of the normal economic cycle. An economy typically expands for 6-10 years and tends to go into a recession for about six months to 2 years. In economic sense, recession is a general slowdown in economic activity over a long period of time, or a business cycle contraction. During recessions, many macroeconomic indicators vary in a similar way. Production as measured by Gross Domestic Product (GDP), employment, investment, spending, capacity utilization, household incomes, business profits and inflation fall during recessions, bankruptcies and the unemployment rates rises.

Engineering education is the activity of teaching knowledge and principles related to the professional practice of engineering. It includes the initial education for becoming an engineer and any advanced education and specializations that follow. Engineering graduates passing out from educational institutions have to fulfil modern and high standard requirements that are needed by industry.

In the present scenario, the output of engineering graduates is increasing due to which the unemployment rate has also been increasing. The quality of education has also become more important during the recession. Many students are hesitating to join in the engineering courses as the employment rate for engineers has been decreased. The gap between the technical knowledge and practical knowledge may also lead to unemployment in these present situations. They are looking towards other subjects like science, management and chartered accountant courses, shown in Figure.1.

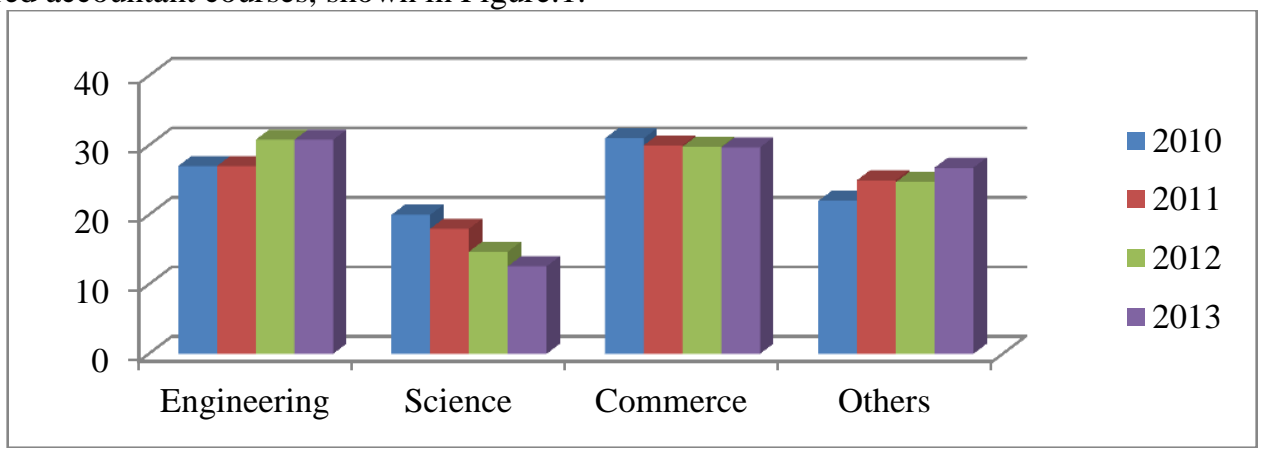

Figure.1. Percentage of students admitted in different streams (Source: CSR-GHRDC B-School Survey 2013) 
During the recession the company's hire the engineering graduates who are having extra ordinary skills, creativity and good communication skills. Due to heavy competition the engineering education has become the minimum qualification for the students. Engineering colleges play a vital role in developing the knowledge and skills of the graduates at all levels. Employment structure of an economy is the normal instrument that can cause a change in inequality either way, i.e. an increase or a decrease in the inequality. Provision of increasing employment opportunities both in urban and rural areas to solve the problem of unemployment has been recognized as an important objective of economic planning in India.

\section{Impact Of Recession On Employment}

The recession is seeing many recent engineering graduates suffering in the employment arena. With more people being laid off from their jobs every single day, it makes it difficult for employers to take on new graduates. One of the troubles that many engineering graduates are suffering is "being overqualified" for the jobs they were applying for. Overall unemployment has suffered drastically, yet indicators that promote employment have shifted, making it a possible concern in the future. Today, unemployment is up, jobs are scarce, and layoffs have become common across the organizations. Forced to implement reductions in the workforce, companies are downsizing, creating an environment of changing work roles, growing complexity and uncertainty to the point of fearing permanent job loss.

$>$ Engaged employees (28\%) work with passion and feel a profound connection to their companies. They drive innovation and move the organization forward.

$>$ Not-engaged employees (54\%) are essentially "checked out." They're sleepwalking through their workday, putting time-but not energy or passion into their work.

$>$ Actively disengaged employees (18\%) aren't just unhappy at work: they're busy acting out their unhappiness. Every day these workers undermine what their engaged co-workers accomplish.

Throughout the last decade, engaged employees ranged from 26 to 30 percent, while actively disengaged employees ranged from 15 to 20 percent. Surprisingly enough in these recessionary times, the actively disengaged category has increased by just one percent, while engaged has dropped by one percent.

During a recession the company's usually follow this pattern:

1. Stop hiring new workers.

2. Put full time workers on part time.

3. Part time workers have their hours cut.

4. Start laying off workers/redundancies.

\section{Survey Of Working Life Research Programme}

The Survey of Working Life (SoWL) collected information on the employment conditions, work arrangements and job flexibility of employed people in New Zealand in the March 2008 quarter. The Department of Labour initiated this survey and worked closely with Statistics New Zealand to develop the SoWL. The survey was run as a supplement to the Household Labour Force Survey in the March 2008 quarter. It is intended the SoWL be regularly repeated so that changes in people's employment conditions can be monitored. The main topics covered by the SoWL are:

$>$ Length of time in main job;

$>$ Employment relationship in main job (temporary including type of temporary employment, permanent, employer, self-employed);

$>$ Working times and hours;

$>$ Work at home;

$>$ Job flexibility in main job;

$>$ Employer-funded study and training;

$>$ Work-related health and safety;

$>$ Annual leave entitlement in main job;

$>$ Type of employment agreement in main job (collective or individual);

$>$ Union membership in main job;

$>$ Satisfaction with main job and with work-life balance.

The global financial crisis of 2007 has cast its long shadow on the economic fortunes of many countries, resulting in what has often been called the 'Great Recession'. What started as seemingly isolated turbulence in the sub-prime segment of the US housing market mutated into a full blown recession by the end of 2007. The old proverbial truth that the rest of the world sneezes when the US catches a cold appeared to be vindicated as systemically important economies in the European Union and Japan went collectively into recession by mid-2008.Overall, 2009 was the first year since World War II that the world was in recession, a calamitous turn around on the boom years of 2002-2007. 
The economic slowdown of the advanced countries which started around mid-2007, as a result of subprime crisis in USA, led to the spread of economic crisis across the globe. Many hegemonic financial institutions like Lehman Brothers or Washington Mutual or General Motors collapsed and several became bankrupt in this crisis. According to the current available assessment of the IMF, the global economy is projected to contract by 1.4 per cent in 2009 . Even as recently as six months ago, there was a view that the fallout of the crisis will remain confined only to the financial sector of advanced economies and at the most there would be a shallow effect on emerging economies like India.

\section{Unemployment Rate In Recession}

One of the most widely recognized indicators of a recession is higher unemployment rates. In December 2007, the national unemployment rate was 5.0 percent, and it had been at or below that rate for the previous 30 months. At the end of the recession, in June 2009, it was 9.5 percent. In the months after the recession, the unemployment rate peaked at 10.0 percent (in October 2009). Before this, the most recent months with unemployment rates over 10.0 percent were September 1982 through June 1983, during which time the unemployment rate peaked at 10.8 percent, (shown in Figure.2).

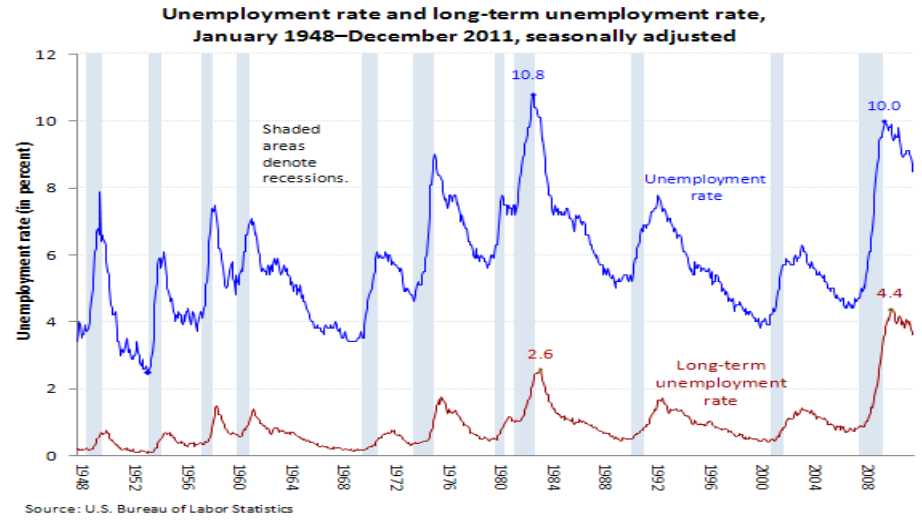

Figure.2. Unemployment Rate during 1948-2009

From the Figure.3, it is noticed that during 2008 to 2009 the unemployment rate and level has increased enormously from 5\% to $9.5 \%$ i.e. almost double the rate during March 2008. It is also found that in 2013 the unemployment rate has come down to $7.5 \%$.

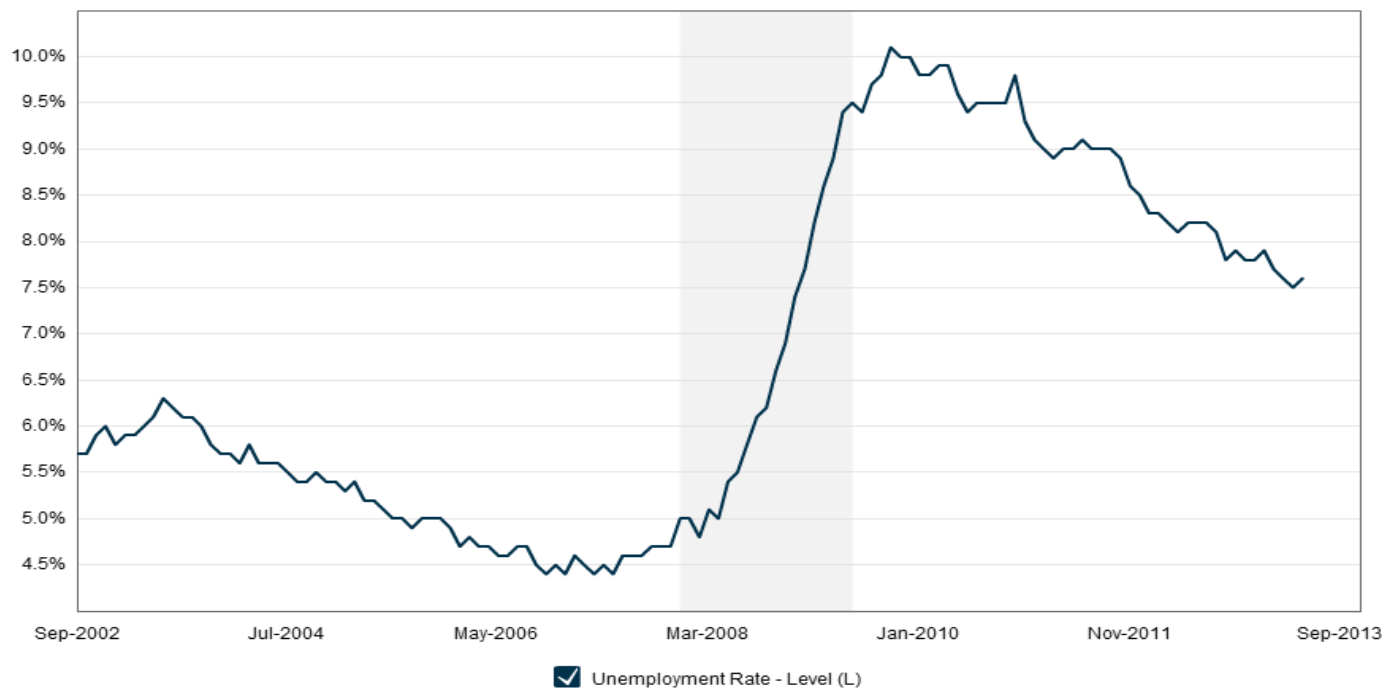

Figure.3. Unemployment Rate - Level during 2002-2013

Based on the U.S. Bureau of Labour Statistics, Figure.4 shows the percentage change in employment during the recession from 1973-2009 at an annual rate of different organisations and companies. This staged response of the employers to the recession means that unemployment rates begin to rise after six to twelve months after a fall in GDP. As is often said, unemployment is a lagging indicator of a recession. 


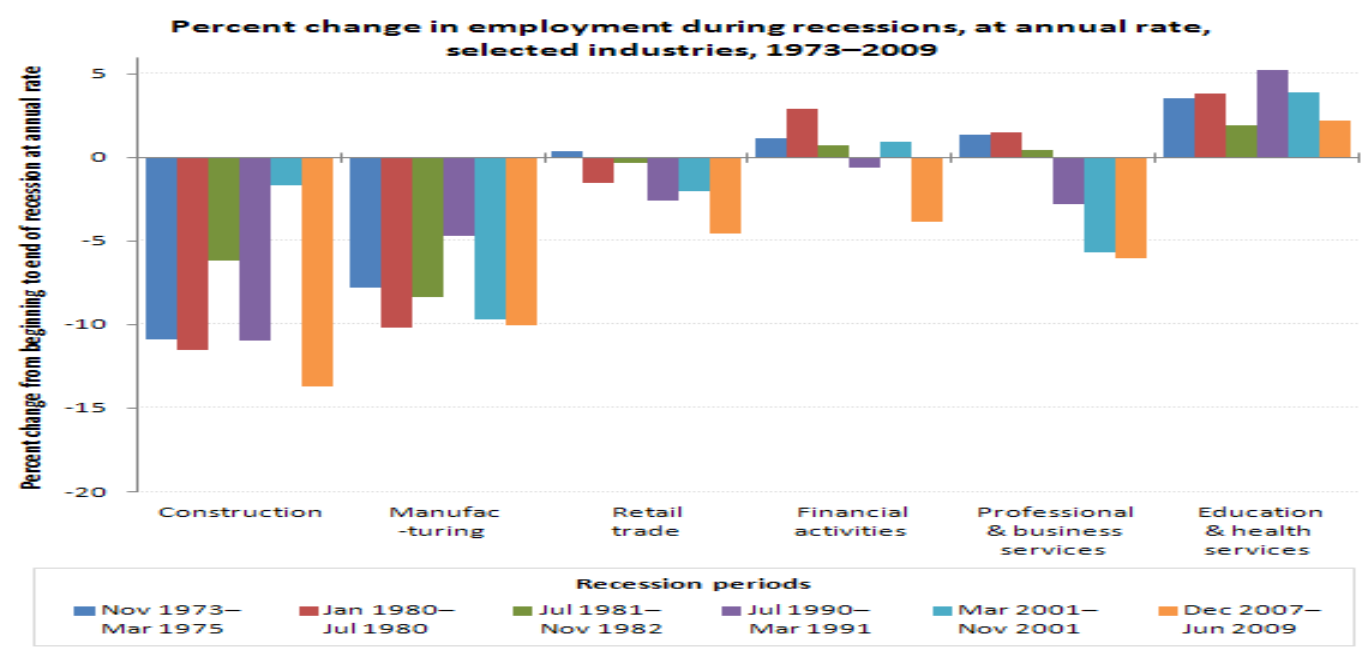

Figure.4. Percentage change in employment during recession 1973-2009

As a result of the halting of new hires, young people who are leaving education (schools, colleges, and universities) and entering the labour market for the first time are likely to face unemployment for some time. The young are often early school leavers, and those with little work experience and hence unlikely to be offered employment when there is a pool of well educated and skilled unemployed workers. The young are also more mobile: they tend to attempt to change jobs in their search for their "ideal" occupation or employment. As a result if they leave their employment, they find it difficult to find new employment and hence join the unemployment queue. Older workers who have been made redundant usually face difficulties in finding a new job, partly as a result of age discrimination, and partly because their skills may be out of date. In general, older workers who are made redundant or who are long term unemployed give up looking for work and join the not in the labour force category, the retired.

\section{Effect Of Unemployment On Engineering Education}

Unemployment has effected engineering education in such as way that millions of engineering graduates are struggling to get placed in the related jobs. The various effects of unemployment on engineering education are:

1. Shifting to other courses: Many students and their parents lack their confidence in engineering education at the time of recession and they are shifting towards the other degrees like arts, commerce, science, animation, chartered accounts, etc., because after completion of engineering education they are not able to get the related jobs.

2. Discouraging others to enter into engineering education: The unemployed engineering students are discouraging others who are desirous of joining in engineering, not to opt this field because already they are facing with unemployment problem.

3. Leads to Frustration: The unemployed engineering youth will ultimately become frustrated. In depression, we don't know in what way they may behave which is not good for a developing economy like India.

4. Waste of Government Money: The central and state governments are spending very huge amounts on engineering education. It will be a waste of money, if the engineering students are not going to get employment and remain idle.

5. Waste of Parents' Money: Parents are also spending a lot of amount on the engineering education of their children with a hope that they will get good jobs and see them in their old age. Their money will be wasted if their children are not going to get any job.

6. Becoming burden to Parents: The unemployed engineering youth will become a white elephant to their parents, which is not a good phenomenon either to the parents or to their children.

7. Becoming burden to the Society: The unemployed engineering graduate will not only become a burden to their parents but also to the society, because they become unproductive citizens of the country.

8. Dearth in the supply of engineers in future: Because of losing confidence in engineering studies students are not opting engineering courses now and shifting to other courses. As a result of this, there will be a danger of dearth in the supply of engineers in future. It is really an alarming thing to be noted.

9. Effect on engineering colleges: Seeing the unemployed engineering youth and also getting discouragement from them many new students are not joining in engineering colleges. Because of this, the engineering colleges are affected a lot. Many colleges are now-a-days closing because of lack of admissions or very low admissions. 
10. Chaos about engineering studies: The ultimate effect of unemployment of engineering youth is chaos about engineering studies in future. We don't not what is going to happen to the engineering field in future if this trend is going on for a number of years.

\section{Future Of Engineering Education}

Change is the only constant in today's times. We too have made changes by keeping the basics in place. Change also carries it with the seeds of transformation and greater potential and possibilities. It is the time to look inwards to get to the basics and make the foundation strong. The survey results should be read not just to take the rating and rankings but also to know, assess and evaluate overall situation existing in the present days.

It is only a matter of time to produce a quality of education a keen interest in the engineering education. If we correct for those factors, the difference between engineering education and other educations can disappear. The scenario in the corporate world is fiercely competitive, uncertain and ambiguous in many ways. In order to respond to globalisation and expand vertically, the engineering colleges should touch the global boundaries by offering quality technical education.

\section{Steps to boost up engineering education:}

Keeping the engineering students unemployed is not good either for their families or for the nation. Basically, no country will be developed without the support of engineers. So, steps should be taken to remove this position and give a bright future to the engineering aspirants. Following steps will to a large extent help to remove this dreadful situation.

1. Importance should be given to the quality based education.

2. Job guarantee should be given to every engineering student.

3. Stipend should be given to the unemployed engineering graduates.

4. Confidence should be created for those who are seeking admissions in the engineering colleges.

5. Right job to the right branch should be encouraged, so that they will feel happy because they have selected a right group.

6. Encourage fresh engineers to research work, so that they can have bright future.

7. Make a stream of engineering very strong, so that the students, the parents and the society will get a strong belief in engineering education.

8. Importance should be given to the engineering education, so that the difference between other education and engineering education will be recognized.

9. In order to respond to the globalisation, the engineering studies should touch the global boundaries and should not confine to national boundaries only.

10. Give importance to practical field of engineering, so that the fresh graduates may get employment easily or they themselves take self-employment.

\section{Conclusion}

In the 21 st century, education systems face the dual challenge of equipping students with the new knowledge, skills and values needed to be competitive in a global market while at the same time producing graduates who are responsible adults, good citizens both of their country and of the world. Thus, globalization challenges us to rethink not only how much education is needed but also its ultimate purposes. Globalization has had many obvious effects on educational technology and communication systems change the way education is delivered as well as roles played by both teachers and students. The development of this technology is facilitating the transition from an industrial based society to an information-based one.

Recession has threatened the corporate to hire in bulk and have wide bench strength. It has also tightened the measures for human resource management in all organisations. At the time of recession and post recession, the things become complicated for corporations. However the challenges of human resource management differ from industry to industry and firm to firm. The recession is the temporary economic climate of the business world. The recession is a good opportunity for engineering graduates to introduce the changes to the organization. In order to respond to globalisation and expand vertically, the engineering colleges should touch the global boundaries by offering quality technical education. Future is engineers' only.

\section{References}

[1] Chapman, B.J., P.N. Junankar\& C.A. Kapuscinski (1992 ) "Projections of Long Term Unemployment", Australian Bulletin of Labour, Vol. 18, No. 3, September 1992, pp.195-207.

[2] Natarajan, R. (2002). Emerging trends in engineering education- Indian perspective. In the Proceedings of the Sixteenth Australian International Conference, Hobart, Australia.

[3] Patro, C.S. (2012). A Study on Adaptability of Total Quality Management in Engineering Education Sector. International Journal of Quality Assurance in Engineering and Technology Education, 2(4), 25-37.

[4] Patro, C.S. (2013). Human Resource Management: An Optimistic Approach at the time of Recession.IOSR Journal of Business and Management, 9(6), 37-41. 
[5] Porter, M. E. (1985). The competitive advantage. New York, NY: Free Press.

[6] Survey of Working Life: March 2008 quarter, retrieved from http://www.stats.govt.nz/ browseforstats/income-andwork/employmentandunemployment/SurveyOfWorkingLife_HOTPMar08qtr.aspx.

[7] Temponi, C. (2005). Continuous improvement framework: Implications for academia. Quality Assurance in Education, 13(1), 17-36. doi:10.1108/09684880510578632.

[8] The Recession of 2007-2009. (2012).U.S. Bureau of labor statistics. Retrieved from www.bls.spotlight.pdf.

[9] Unemployment Rate (2013), retrieved from http://www.macrotrends.net/1339/unemployment-rate-last-ten-years.

[10] Retrieved date from CSR-GHRDC B-School Survey 2013. 